\title{
Acrodermatitis continua Hallopeau
}

\section{Acrodermatitis continua Hallopeau}

Julia Nowowiejska, Anna Baran, Julita A. Krahel, Iwona Flisiak

Department of Dermatology and Venereology, Medical University in Bialystok, Poland

Klinika Dermatologii i Wenerologii, Uniwersytetu Medycznego w Białymstoku, Polska

Dermatol Rev/Przegl Dermatol 2021, 108, 52-58

DOI: https://doi.org/l0.5 I |4/dr.202I. 105894

\author{
CORRESPONDING AUTHOR/ \\ ADRES DO KORESPONDENCJI: \\ lek. Julia Nowowiejska \\ Klinika Dermatologii \\ i Wenerologii \\ Uniwersytet Medyczny \\ w Białymstoku \\ e-mail: \\ julia.nowowiejska@umb.edu.pl
}

\begin{abstract}
Introduction. Acrodermatitis continua Hallopeau $(\mathrm{ACH})$ is a rare form of psoriasis. Sterile pustules are usually located in the area of the fingertips and nails at the site of injury or infection. Nail lesions are always present.

Case report. A 65-year-old man was admitted to the Department of Dermatology for diagnostics and treatment of lesions of the skin and fingernails that developed as a consequence of an injury. Initially, he was treated on an outpatient basis with topical glucocorticoids, without improvement. On admission, numerous pustules, maceration of the epidermis, severe hyperkeratosis of the skin in distal parts of fingers and soles, and swollen, red nail folds with dystrophy of many finger and toe nail plates were observed. Acitretin was introduced. An improvement in the condition of the skin was observed during the hospitalisation. An outpatient follow-up was recommended, during which further improvement was noted.

Conclusions. Acrodermatitis continua Hallopeau is a chronic and progressive dermatosis that can lead to irreversible complications. The nail apparatus becomes affected early. Untreated acrodermatitis continua Hallopeau may lead to onychodystrophy or anonychia, and even to osteolysis of distal phalanges. So far, no specific guidelines for the treatment of acrodermatitis continua Hallopeau have been developed.
\end{abstract}

\section{STRESZCZENIE}

Wprowadzenie. Ropne ciągłe krostkowe zapalenie skóry palców jest rzadką odmianą łuszczycy krostkowej. Jałowe krosty lokalizują się zwykle w okolicy opuszek palców i paznokci w miejscu urazu lub infekcji, zawsze współwystępują zmiany paznokciowe.

Opis przypadku. Do kliniki dermatologii został przyjęty 65-letni mężczyzna w celu diagnostyki i leczenia zmian skórnych i paznokciowych powstałych po urazie. Początkowo leczony był ambulatoryjnie glikokortykosteroidami podawanymi miejscowo, terapia była jednak nieskuteczna. Przy przyjęciu stwierdzono w obrębie skóry dystalnych części palców rąk i podeszew liczne krosty, macerację naskórka, nasiloną hiperkeratozę, obrzęknięte, zaczerwienione wały paznokciowe z dystrofią wielu płytek paznokciowych rąk i stóp. Zastosowano acytretynę. Już w trakcie hospitalizacji zaobserwowano poprawę stanu skóry. Za- 
lecono kontrolę w trybie ambulatoryjnym, podczas której odnotowano dalszą poprawę w czasie leczenia.

Wnioski. Ropne ciągłe krostkowe zapalenie skóry palców jest dermatozą przewlekłą i postępującą, która może doprowadzić do nieodwracalnych powikłań. Wcześnie dochodzi do zajęcia aparatu paznokciowego. Nieleczone ropne ciągłe krostkowe zapalenie skóry palców może być przyczyną onychodystrofii lub anonychii, a nawet osteolizy paliczków dystalnych. Dotychczas nie opracowano wytycznych leczenia ropnego ciągłego krostkowego zapalenia skóry palców.

Key words: acrodermatitis continua Hallopeau, psoriasis, acitretin, onycholysis.

Słowa kluczowe: acrodermatitis continua Hallopeau, łuszczyca, acytretyna, onycholiza.

\section{INTRODUCTION}

Acrodermatitis continua of Hallopeau $(\mathrm{ACH})$ is considered a type of pustular psoriasis [1, 2]. This disease is so rare that the exact frequency of its occurrence is unknown [1]. It usually affects middle-aged women, although the disease is possible in both sexes at any age [3]. Skin lesions are sterile pustules (new lesions form characteristic lake of pus that carries the nail away) and are usually located near the fingertips (more often than in distal parts of toes) and nails, at the site of a past injury or infection. They are always accompanied by nail lesions [1-4]. Eruptions may be limited to the original site of occurrence or may spread proximally to hands and forearms or feet and shins [3]. There are also reports of involvement of mucous membranes of the eyes, mouth, and urethra [3].

\section{OBJECTIVE}

Presentation of a case of a rare dermatosis, such as $\mathrm{ACH}$, and a concise review of the literature along with available treatment methods.

\section{CASE REPORTS}

A 65-year-old man with a negative individual and family history of skin diseases was admitted to the Teaching Department of Dermatology for the diagnosis and treatment of skin lesions in soles and hands that had been present for several years, and nail lesions persisting for 10 years, resulting from an injury. He was initially treated on an outpatient basis with topical glucocorticoids and keratolytic preparations without any significant improvement. Skin lesions gradually intensified, causing pain when performing basic activities. Upon admission, numerous pustules,

\section{WPROWADZENIE}

Ropne ciągłe krostkowe zapalenie skóry palców (łac. acrodermatitis continua Hallopeau - ACH) jest uważane za odmianę łuszczycy krostkowej [1, 2]. Schorzenie to jest na tyle rzadkie, że nie jest znana dokładna częstość występowania [1]. Zwykle dotyczy kobiet w średnim wieku, ale możliwe jest zachorowanie u obu płci w każdym wieku [3]. Zmiany skórne mają postać jałowych krost (nowe zmiany tworzą charakterystyczne jeziorka ropy) i lokalizują się zazwyczaj w okolicy opuszek palców (częściej rąk niż stóp) oraz paznokci, w miejscu urazu lub infekcji, zawsze współwystępują zmiany paznokciowe [1-4]. Wykwity mogą ograniczać się do pierwotnego miejsca wystąpienia lub rozprzestrzeniać się proksymalnie, zajmując ręce i przedramiona lub stopy i podudzia [3]. Opisywane są także przypadki zajęcia błon śluzowych oczu, jamy ustnej i cewki moczowej [3].

\section{CEL PRACY}

Przedstawienie przypadku rzadkiej dermatozy, jaką jest $\mathrm{ACH}$, oraz zwięzłego przeglądu piśmiennictwa i dostępnych metod leczenia.

\section{OPIS PRZYPADKU}

Do kliniki dermatologii został przyjęty 65-letni mężczyzna z negatywnym osobniczym i rodzinnym wywiadem w kierunku chorób skóry w celu diagnostyki i leczenia zmian skórnych w obrębie podeszew i rąk. Zmiany skórne trwały od kilku lat, zmiany paznokciowe od 10 lat, powstały po urazie. Początkowo leczony był ambulatoryjnie miejscowo stosowanymi glikokortykosteroidami i preparatami keratolitycznymi, terapia była jednak nieskuteczna. Zmiany 

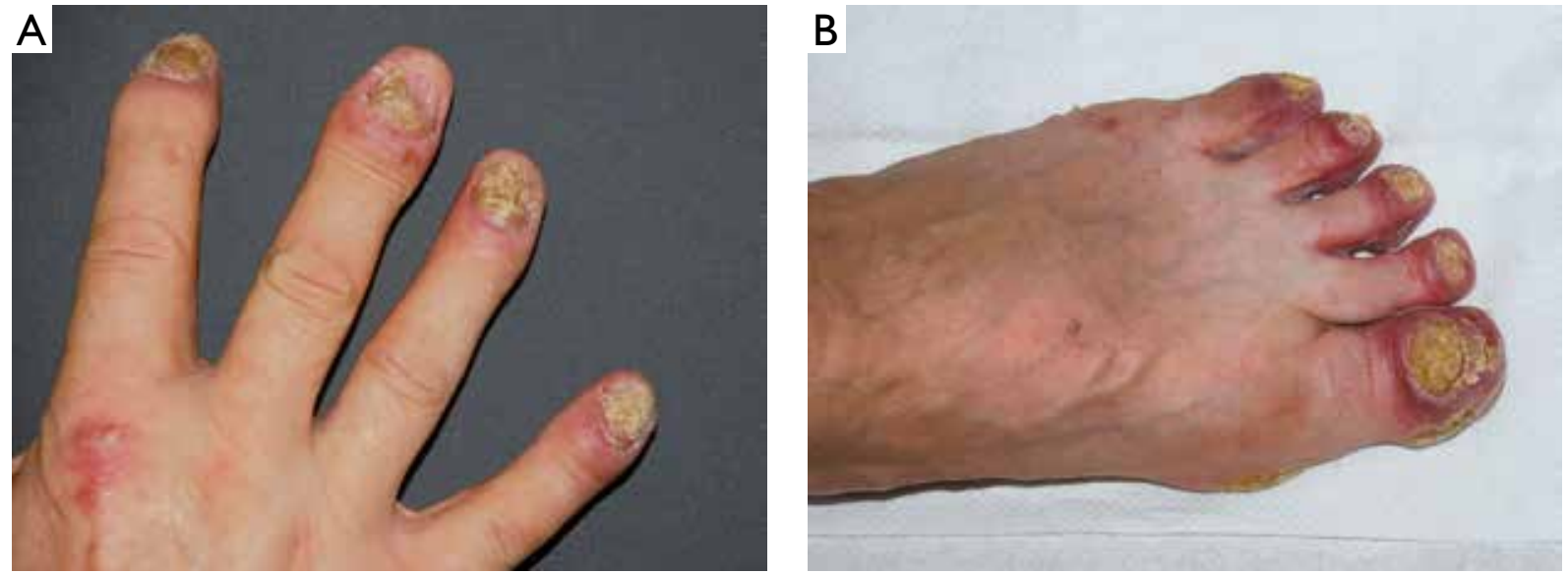

Figure I. A, B - Clinical presentation at admission - oedema and erythema of distal parts of fingers and toes, onychodystrophy Rycina I. A, B - Obraz kliniczny podczas przyjęcia - obrzęk i rumień dystalnych części palców rąk i stóp, dystrofia płytek paznokciowych

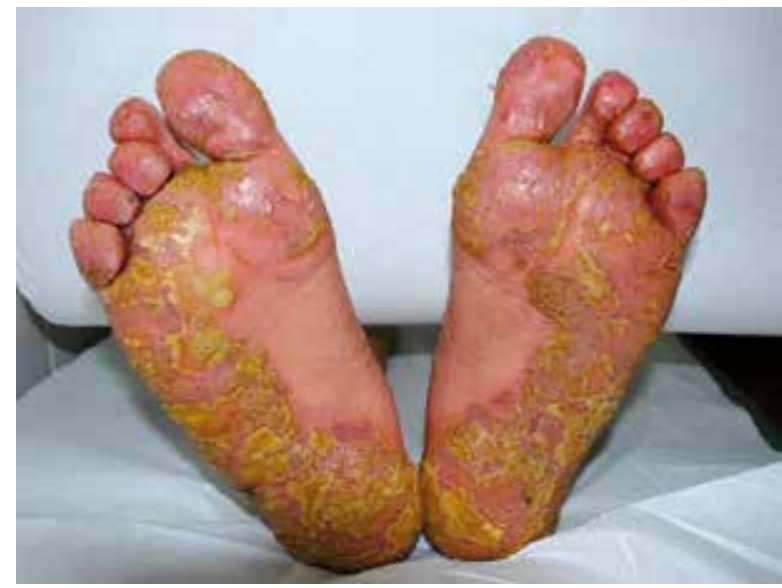

Figure 2. Clinical presentation at admission - hyperkeratosis and maceration on plantar parts of feet

Rycina 2. Obraz kliniczny podczas przyjęcia - hiperkeratoza i maceracja podeszew stóp

maceration, and cracks in the epidermis, severe hyperkeratosis in distal parts of hands and soles, and swollen, red nail folds with dystrophy of multiple finger and toe nail plates were observed (figs. 1,2). Linear, highly keratinised papules (Köbner phenomenon) were visible within the skin of the back (fig. 3). Laboratory tests showed an increased level of CRP (C-reactive protein). Culture of swabs from skin lesions demonstrated presence of Proteus vulgaris +++ susceptible to gentamicin. No abnormalities were found in the previously performed outpatient $\mathrm{X}$-ray of the hand joints. A skin biopsy was taken for histopathological examination from the affected plantar skin. Based on the data from the history, and clinical and microscopic presentation, the diagnosis of purulent continuous phalangitis was made. Acitretin at the dose of $30 \mathrm{mg} /$ day $(0.5 \mathrm{mg} / \mathrm{kg} \mathrm{bw} /$ day $)$ and topical preparations (salicylic urea ointment, tar ointment, gentamicin ointment - according to the bacte-

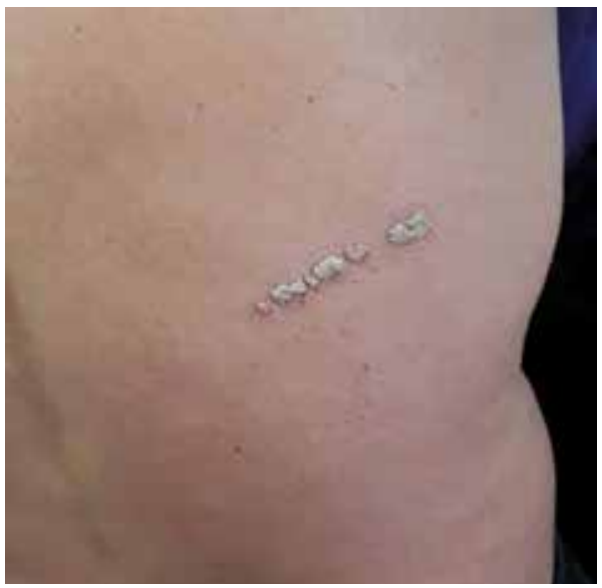

Figure 3. Köbner phenomenon on the skin of the back

Rycina 3. Objaw Köbnera w obrębie skóry pleców

stopniowo się nasilały, powodując dolegliwości bólowe przy wykonywaniu podstawowych czynności. Przy przyjęciu w obrębie skóry dystalnych części palców rąk i podeszew stwierdzono liczne krosty, macerację i pęknięcia naskórka, nasiloną hiperkeratozę, obrzęknięte, zaczerwienione wały paznokciowe z dystrofią wielu płytek paznokciowych rąk i stóp (ryc. 1, 2). W obrębie skóry pleców widoczne były linijnie układające się, silnie zrogowaciałe grudki (objaw Köbnera) (ryc. 3). W badaniach laboratoryjnych z odchyleń stwierdzono podwyższone stężenie białka C-reaktywnego (C-reactive protein - CRP), w posiewie ze zmian skórnych - Proteus vulgaris +++, wrażliwy m.in. na gentamycynę. W wykonanym wcześniej ambulatoryjnie RTG stawów rąk nie stwierdzono nieprawidłowości. Pobrano wycinek zmienionej chorobowo skóry podeszwy do badania histologicznego. Na podstawie danych z wywiadu, obrazu klinicznego i mikroskopowego ustalono rozpoznanie ropnego 

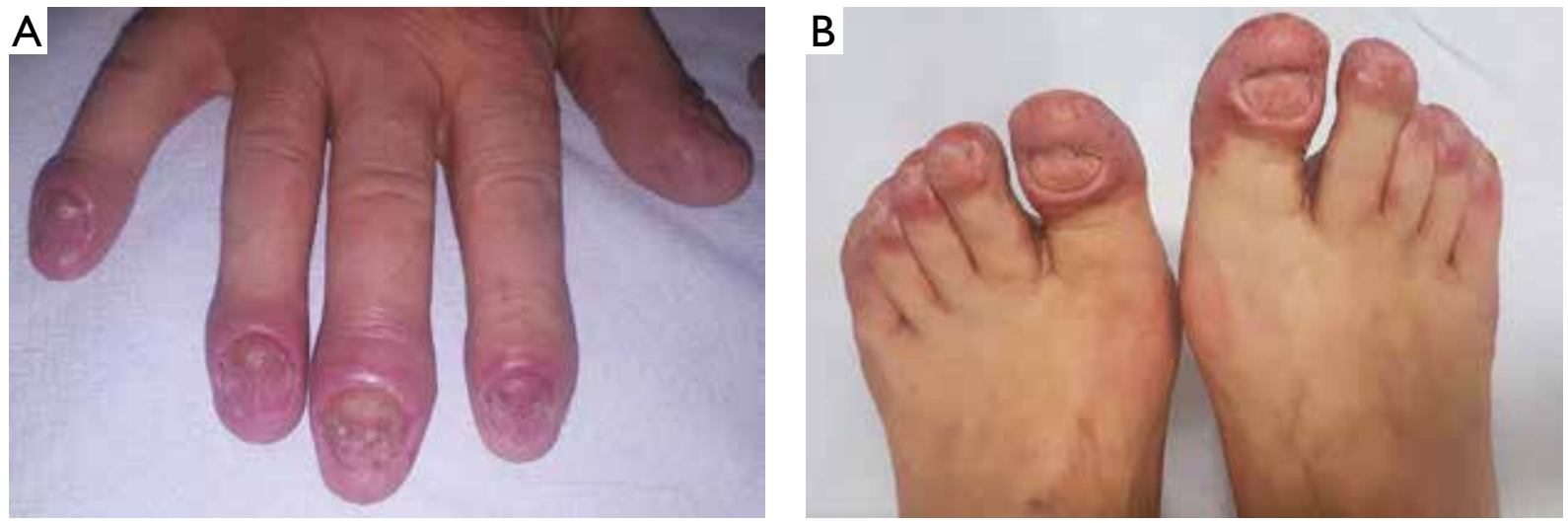

Figure 4. A, B - Condition after 2 weeks of treatment with acitretin and topical agents during the hospitalisation

Rycina 4. A, B - Stan po 2 tygodniach leczenia acytretyną i preparatami miejscowymi podczas hospitalizacji

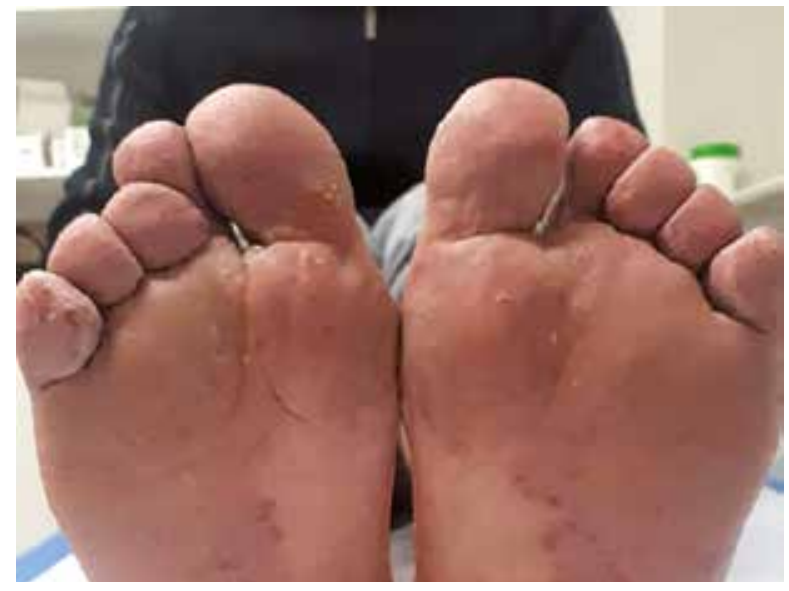

Figure 5. Condition after 2 months of treatment with acitretin and topical agents in outpatient setting, recorded at a follow-up visit

Rycina 5. Stan po 2 miesiącach leczenia acytretyną i preparatami miejscowymi w trakcie kontroli ambulatoryjnej

rial culture) were included in the treatment. Clinical improvement was observed during the hospitalisation (fig. 4). The patient was discharged home with the recommendation of further outpatient follow-up, during which further progress of the treatment was noted, with good tolerance and the disappearance of subjective symptoms (fig. 5).

\section{DISCUSSION}

Acrodermatitis continua of Hallopeau is considered a localised form of pustular psoriasis [1, 2]. As in the case of psoriasis vulgaris, genetic factors are postulated in the pathogenesis of the $\mathrm{ACH}$ variant. Probable mutations conditioning the occurrence of this variant of psoriasis are mutations in IL36RN, CARD14 and AP1S3 genes [1].

Acrodermatitis continua of Hallopeau is a chronic, progressive, and recurrent dermatosis that can lead to irreversible complications [1,2]. In the course of the disease, the nail apparatus is involved early. Howev- ciągłego zapalenia palców. Włączono do leczenia acytretynę w dawce $30 \mathrm{mg} /$ dobę $(0,5 \mathrm{mg} / \mathrm{kg}$ m.c./dobę) oraz preparaty miejscowe (maść salicylowo-mocznikowa, maść dziegciowa, maść z gentamycyną - zgodnie z posiewem). Już w trakcie hospitalizacji zaobserwowano poprawę kliniczną (ryc. 4). Pacjenta wypisano do domu z zaleceniem kontroli w trybie ambulatoryjnym, podczas której odnotowano dalszą poprawę z dobrą tolerancją leczenia oraz ustąpieniem objawów subiektywnych (ryc. 5).

\section{OMÓWIENIE}

Ropne ciągłe krostkowe zapalenie skóry palców jest uważane za zlokalizowaną postać łuszczycy krostkowej [1, 2]. Tak jak w przypadku łuszczycy zwykłej, w patogenezie odmiany $\mathrm{ACH}$ postuluje się udział czynników genetycznych. Prawdopodobnymi mutacjami warunkującymi wystąpienie tego wariantu łuszczycy są mutacje genów IL36RN, CARD14 oraz AP1S3 [1]. 
er, the disease rarely affects all fingers and is usually asymmetric [1]. In the literature there are reports of cases in which, similarly to our patient, all fingers of both hands were involved $[4,5]$. Untreated $\mathrm{ACH}$ may lead to onychodystrophy or anonychia, and even osteolysis of distal phalanges and syndactyly, which indicates the need for early diagnosis and implementation of treatment and radiological control [1]. There are also reports of coexisting psoriatic arthritis in patients with $\mathrm{ACH}$ [6]. There are reports of a possible conversion of $\mathrm{ACH}$ to generalised pustular psoriasis, including the potentially lethal variant of von Zumbusch [1]. Due to serious complications, and even a risk of death, early diagnosis and implementation of adequate treatment are of key importance. Unfortunately, ACH is often misdiagnosed, usually confused with contact dermatitis, bacterial, fungal, or viral paronychia $[1,4]$. However, the key disease for the differentiation from $\mathrm{ACH}$ is palmoplantar pustulosis (PPP) [1]. The most important features of ACH, distinguishing it from PPP, are the appearance of lesions as a consequence of an injury, and their usual asymmetric character, which is rarely observed in PPP. Moreover, in $\mathrm{ACH}$ there is always nail involvement and lesions are purulent, which is not typical for PPP, just like osteolysis (table 1) [1]. The diagnosis of $\mathrm{ACH}$ is based primarily on the history and physical examination. However, a skin and/or nail biopsy is worth performing [1, 2]. Laboratory tests do not show any significant deviations from the normal [3]. Dermoscopy may also be helpful in the diagnostic process because it allows observation of features characteristic of $\mathrm{ACH}$, which sometimes are not clinically visible. These are usually foci of yellow-white hyperkeratosis and exfoliation as well as pustules. Punctate bleeding or linear blood vessels can also be found [7].

The therapy of $\mathrm{ACH}$ is difficult, especially because no specific treatment guidelines have been developed so far $[1,2]$. Apart from the standard topical and general treatment of psoriasis, particularly in the case of failure of previous therapeutic attempts, the use of biological drugs seems to be promising. However,
Jest to dermatoza przewlekła, postępująca i nawracająca, która może prowadzić do nieodwracalnych powikłań [1, 2]. W przebiegu choroby wcześnie dochodzi do zajęcia aparatu paznokciowego, jednak dermatoza rzadko zajmuje palce rąk i zwykle przebiega asymetrycznie [1]. W piśmiennictwie można znaleźć opisy przypadków, w których - podobnie jak u naszego pacjenta - doszło do zajęcia wszystkich palców obu rąk $[4,5]$. Nieleczone ACH może prowadzić do onychodystrofii lub anonychii, a nawet osteolizy paliczków dystalnych i syndaktylii, co powoduje konieczność jak najszybszego postawienia diagnozy i wdrożenia leczenia oraz kontroli radiologicznej [1]. Opisywane są także przypadki współistnienia łuszczycowego zapalenia stawów u chorych z ACH [6]. Istnieją doniesienia o możliwej konwersji ACH do uogólnionej łuszczycy krostkowej, w tym potencjalnie letalnego wariantu von Zumbusch [1]. Ze względu na poważne powikłania, a nawet zagrożenie życia, kluczowe jest wczesne ustalenie rozpoznania i wdrożenie adekwatnego leczenia. Niestety ACH jest często nieprawidłowo diagnozowane, zwykle mylnie rozpoznawane jako kontaktowe zapalenie skóry [1, 4]. Najważniejszym schorzeniem, które powinno być różnicowane z $\mathrm{ACH}$, jest łuszczyca krostkowa dłoni i podeszew (palmoplantar pustulosis - PPP) [1]. Najważniejszymi cechami ACH odróżniającymi je od PPP jest pojawianie się zmian po urazie i zazwyczaj występująca asymetria, co rzadko jest obserwowane w przypadku PPP. Ponadto w ACH zawsze dochodzi do zajęcia paznokci, a zmiany mają charakter ropny, co nie jest typowe dla PPP, podobnie jak osteoliza (tab. 1) [1]. Rozpoznanie ACH ustala się przede wszystkim na podstawie wywiadu i badania przedmiotowego, warto też wykonać biopsję skóry i/lub paznokci $[1,2]$. Badania laboratoryjne nie wykazują istotnych odchyleń od normy [3]. Pomocne w procesie diagnostycznym może być także badanie dermoskopowe, które pozwala zaobserwować cechy charakterystyczne dla ACH niewidoczne klinicznie. Są to zwykle ogniska żółtobiaławej hiperkeratozy i złuszczania oraz krosty, ponadto można stwierdzić punkcikowate krwawienie czy linijne naczynia krwionośne [7].

Table I. The comparison of acrodermatitis continua of Hallopeau and palmoplantar pustulosis [I]

Tabela I. Porównanie ropnego ciągłego krostkowego zapalenia skóry palców z łuszczycą krostkową dłoni i podeszew [I]

\begin{tabular}{ll}
\multicolumn{1}{c}{ ACH } & \multicolumn{1}{c}{ PPP } \\
$\begin{array}{l}\text { Often a consequence of a past injury/Często poprzedzone } \\
\text { urazem }\end{array}$ & Rarely preceded by an injury/Rzadko poprzedzona urazem \\
\hline $\begin{array}{l}\text { Early involvement of nails/Nczesne zajęcie aparatu } \\
\text { paznokciowego }\end{array}$ & Nails not always affected/Paznokcie nie zawsze zajęte \\
\hline $\begin{array}{l}\text { Rare involvement of all fingers and toes, asymmetrical } \\
\text { involvement of fingers and toes/Rzadko zajęcie wszystkich palców, } \\
\text { asymetryczne zajęcie palców }\end{array}$ & \begin{tabular}{l} 
Often bilateral and symmetrical involvement of fingers and toes/ \\
\hline Osteolysis of phalanges/Osteoliza paliczków
\end{tabular} \\
\hline
\end{tabular}

ACH - acrodermatitis continua Hallopeau, PPP - palmoplantar pustulosis

ACH - ropne ciqgłe krostkowe zapalenie skóry palców, PPP - łuszczyca krostkowa dłoni i podeszew 
the ones most often used in the treatment of psoriasis vulgaris are not always effective in $\mathrm{ACH}[1,8]$. In the case of the reported patient, the inclusion of acitretin resulted in a significant improvement in the condition of the skin and nails, as well as an improvement in the quality of life. From the group of biological drugs, there are reports on the effectiveness of TNF-a inhibitors, such as infliximab, adalimumab, and etanercept, as well as IL-17 inhibitors (i.e. secukinumab and ixekizumab), IL-12/23 inhibitors (i.e. ustekinumab), and an antagonist of the IL-1 receptor (i.e. anakinra) $[1,3]$. Most reports in the literature concern adalimumab and infliximab, while the latter was often accompanied by a secondary decrease in effectiveness, appearance of positive titres of antinuclear antibodies and the need for combined therapy. There are fewer reports of inclusion of IL-17 inhibitors in ACH therapy, and one report contains even the information about provoking psoriasis-like lesions within fingers and nails after initiating a therapy with secukinumab [3]. Brodalumab, an inhibitor of the IL-17RA receptor, may also be an effective drug in $\mathrm{ACH}$. It prevents binding not only of IL-17A, but also of IL-17C, E, and F. It was proven to be effective in the treatment of generalised pustular psoriasis, as well as in ACH resistant to treatment with inhibitors of IL-17A alone [9]. There are also reports of cases of effective use of the phosphodiesterase 4 inhibitor - apremilast - not only in plaque psoriasis and psoriatic arthritis, but also in ACH [10]. Moreover, due to the mutation of the IL-36 gene as a potential causative factor, spesolimab, a human antibody to IL-36, still under research, seems to be promising $[1,11]$.

\section{CONCLUSIONS}

Acrodermatitis continua of Hallopeau is a chronic, progressive dermatosis that can lead to irreversible complications. In the course of the disease, the nail apparatus is affected, and untreated ACH may lead to onychodystrophy or anonychia, and even to osteolysis of distal phalanges. Lesions are usually unilateral and asymmetrical, although all fingers and toes may become affected. So far, no specific guidelines for the treatment of $\mathrm{ACH}$ have been developed, although in practice, standard local and general treatment of psoriasis is used. Introduction of biological drugs seems to be promising.

\section{CONFLICT OF INTEREST}

The authors declare no conflict of interest.
Leczenie ACH jest trudne, zwłaszcza że dotychczas nie opracowano wytycznych $[1,2]$. Oprócz standardowego leczenia miejscowego i ogólnego łuszczycy, szczególnie w przypadku dotychczasowych niepowodzeń terapeutycznych, obiecujące wydaje się zastosowanie leków biologicznych, przy czym nie zawsze te najczęściej stosowane w terapii łuszczycy zwykłej są skuteczne w odmianie $\mathrm{ACH}[1,8]$. W przypadku opisanego pacjenta włączenie acytretyny spowodowało istotną poprawę stanu skóry i paznokci oraz polepszenie jakości życia. Według doniesień z literatury spośród leków biologicznych skuteczne są inhibitory TNF-a, takie jak infiksymab, adalimumab i etanercept, a także inhibitory IL-17, tj. sekukinumab i iksekizumab, inhibitory IL-12/23, tj. ustekinumab, oraz antagoniści receptora dla IL-1, tj. anakinra [1, 3]. W piśmiennictwie najczęściej wymienia się adalimumab i infliksymab, przy czym zastosowaniu tego drugiego często towarzyszy wtórny spadek skuteczności, pojawienie się dodatnich mian przeciwciał przeciwjądrowych oraz konieczność prowadzenia terapii łączonej. Rzadziej opisuje się włączenie do terapii ACH inhibitorów IL-17. W jednej z publikacji można znaleźć nawet informację o sprowokowaniu zmian łuszczycopodobnych w obrębie palców i paznokci po rozpoczęciu terapii sekukinumabem [3]. Skutecznym lekiem w ACH może być także brodalumab - inhibitor receptora IL-17RA. Uniemożliwia on wiązanie nie tylko IL-17A, lecz także IL-17C, E i F. Udowodniono, że przynosi on istotne efekty w terapii uogólnionej łuszczycy krostkowej, a także w ACH opornym na leczenie inhibitorami tylko IL-17A [9]. W piśmiennictwie opisano także przypadki skutecznego leczenia inhibitorem fosfodiesterazy 4 - apremilastem, nie tylko łuszczycy plackowatej i łuszczycowego zapalenia stawów, lecz także ACH [10]. Ponadto w związku z mutacją genu IL-36 jako potencjalnym czynnikiem sprawczym obiecujący wydaje się spesolimab, będący ludzkim przeciwciałem IL-36, który jest jeszcze w fazie badań $[1,11]$.

\section{WNIOSKI}

Ropne ciągłe krostkowe zapalenie skóry palców jest przewlekłą, postępującą dermatozą. W przebiegu choroby dochodzi do zajęcia aparatu paznokciowego, a nieleczone $\mathrm{ACH}$ może prowadzić do nieodwracalnych powikłań - onychodystrofii lub anonychii, a nawet osteolizy paliczków dystalnych. Zmiany lokalizują się zwykle jednostronnie i są asymetryczne, ale możliwe jest zajęcie wszystkich palców. Dotychczas nie opracowano wytycznych leczenia $\mathrm{ACH}$, w praktyce stosuje się standardowe leczenie miejscowe i ogólne jak w łuszczycy, a obiecujące wydaje się wprowadzenie leków biologicznych.

\section{KONFLIKT INTERESÓW}

Autorzy nie zgłaszają konfliktu interesów. 


\section{References}

\section{Piśmiennictwo}

1. Smith M.P., Ly K., Thibodeaux Q., Bhutani T., Liao W., Beck K.M.: Acrodermatitis continua of Hallopeau: clinical perspectives. Psoriasis (Auckl) 2019, 9, 65-72.

2. Korman A.M., Rzepka P.V., Sopkovich J.A.: Acrodermatitis continua of Hallopeau. JAMA Dermatol 2018, 154, 1346.

3. Maliyar K., Rodriguez-Bolanos F., O'Toole A., Gooderham M.J.: The use of biologic therapy in the treatment of acrodermatitis continua of Hallopeau: a review. J Cutan Med Surg 2019, 23, 428-435.

4. Crowley E.L., Maliyar K., Rodriguez-Bolanos F., O'Toole A., Gooderham M.J.: Acrodermatitis continua of Hallopeau successfully treated with adalimumab: a case report. SAGE Open Med Case Rep 2019, 7, 2050313X19829620.

5. Alorainy M., Alshaya M., Al-Rikabi A., Ayesh M., Alsaif F.: Acrodermatitis continua of Hallopeau with bone resorption in an 8-year-old patient: a case report. Case Rep Dermatol 2017, 9, 259-264.

6. Khosravi-Hafshejani T., Zhou Y., Dutz J.P.: Acrodermatitis continua of Hallopeau with psoriatic arthritis. J Rheumatol 2019, 46, 437-438.

7. Errichetti E., Stinco G.: Dermoscopy in facilitating the recognition of acrodermatitis continua of Hallopeau. J Dermatol 2017, 44, e286-e287.

8. Balestri R., Rech G., Tasin L., Rizzoli L., Girardelli C.R.: Acrodermatitis continua of Hallopeau successfully treated with secukinumab. J Dermatol Treat 2018, 29, 3-5.

9. Passante M., Dastoli S., Nisticò S.P., Bennardo L., Patruno C.: Effectiveness of brodalumab in acrodermatitis continua of Hallopeau: a case report. Dermatol Ther 2020, 33, e13170.

10. Calleja Algarra A., Aragón Miguel R., Velasco Tamariz V., Prieto Barrios M., LencinaJ.J.A., Alonso C., et al.: Apremilast as a new treatment option for Acrodermatitis continua of Hallopeau. Australas J Dermatol 2019, 60, e237-e238.

11. https://clinicaltrials.gov/ct2/show/NCT03135548. Accessed: 8.06.2020.

Received: 10.06 .2020

Accepted: 13.11 .2020

Otrzymano: $10.06 .2020 \mathrm{r}$.

Zaakceptowano: $13.11 .2020 \mathrm{r}$.

How to cite this article

Nowowiejska J., Baran A., Krahel J.A., Flisiak I.: Acrodermatitis continua Hallopeau. Dermatol Rev/Przegl Dermatol 2021, 108, 52-58. DOI: https://doi.org/10.5114/dr.2021.105894. 